\title{
Annealing temperature modes influence on properties of heterophase nanocomposites based on ceramics "glass - Ag-Pd" systems
}

\author{
Ya.I.Lepikh, T.I.Lavrenova, T.N.Bugayova, \\ N.P.Zatovskaya, P.O.Snigur
}

\author{
Odesa I.Mechnikov National University, Interdepartmental \\ Scientific-educational Physicotechnical Centre of MES and NAS of \\ Ukraine, 2 Dvoryanskaya Str., 65082 Odesa, Ukraine
}

Received March 21, 2014

\begin{abstract}
Temperature formation modes influence on the electric parameters and operational characteristics thick-film elements made of nanocomposite system "glass - Ag-Pd" are investigated. The manufacturing techniques are described, thick-film elements optimum modes manufacturing are determined. The developed optical attachment for thick-film element IR spectroscopy is described. The nanocomposites based on systems "glass $\mathrm{Ag}-\mathrm{Pd}$ " phase structure changing at various formation temperatures was investigated by IR-spectroscopy of reiterated total reflection method. Qualitative and quantitative chemical analyses of conducting thick-film layers are carried out. Film spectra and structure are analyzed.
\end{abstract}

Исследовано влияние температурных режимов формирования толстопленочных элементов из нанокомпозитов системы "стекло - Ag-Pd" на их электрические параметры и әксплуатационные характеристики. Описана технология и определены оптимальные режимы изготовления толстопленочных элементов. Описана разработанная оптическая приставка для ИК спектроскопии толстопленочных әлементов. Методом ИК-спектроскопии многократного полного внутреннего отражения исследовано изменение фазового состава нанокомпозитов на базе систем "стекло - Ag-Pd" при различных температурных режимах при их формировании. Проведены качественный и количественный химический анализы проводящих толстопленочных слоев. Анализируются спектры и структура пленок.

Вплив температурних режимів відпалу на властивості гетерофазних нанокомпозитів на базі систем "скло - Ag-Pd". Я.І.Лепіх, Т.І.Лавренова, Т.М.Бугайова, Н.П.За товська, П.О.Снігур.

Досліджено вплив температурних режимів формування товстоплівкових елементів з нанокомпозитів системи "скло - Ag-Pd" на їхні електричні параметри та експлуатаційні властивості. Описано технологію та визначено оптимальні режими виготовлення товстоплівкових елементів. Описано розроблену оптичну приставку для ІЧ спектроскопії товстоплівкових елементів. Методом ІЧ-спектроскопії багаторазового повного внутрішнього відбивання досліджено зміну фазового складу нанокомпозитів на базі систем "скло - Ag-Pd" при різних температурних режимах при їхньому формуванні. Проведено якісний і кількісний хімічний аналізи проводящих товстоплівкових шарів. Проаналізовано спектри і структуру плівок. 


\section{Introduction}

Under preparation of thick-film conductors, contact platforms and hybrid integrated circuits (HIC) collector elements and solar batteries the nanocomposites based on ceramics "glass - Ag-Pd" heterogeneous systems are widely used [1-3].

However, as investigations show the thick-film element quality is insufficient. The HIC failure connected with the partial or full conductors and contacts destruction occurs already after $2.5-5$ months from the products operation beginning. It is established, that principal causes the ceramic substrate - contact platform - solder contacts poor quality are the following: bad thick-film layer adhesion to a substrate and contact platform functional materials strong dissolution in the solder melt. The researchers have shown that it is connected with the thick-film conducting layer structural - phase features. It has been established, that formation of $\mathrm{AgPd}$ and $\mathrm{Ag}_{2} \mathrm{Pd}_{3}$ intermetallic compounds under conducting pastes annealing process densifies the structure and hinders the contact platform functional material processes diffusion and dissolution in the solder melt. Besides formation in an initial matrix of the phases of complex spatial structure such as $\mathrm{Me}\left(\mathrm{OH}_{2}\right)$ blocks Sn diffusion in a matrix and hinders dissolution of its other components ( $\mathrm{Ag}, \mathrm{Pd})$ in the solder melt. Formation of intermetallic $\mathrm{Ag}_{x}-\mathrm{Pd}_{y}$ compounds and solvate systems is connected with initial components particles dispersiveness [4].

The authors [4-8] mark, that the basic contribution (80-90\% of the general number of failures) in occurrence of failures is given by the defects caused by technological processes. In [9] the low-resistance conducting layers production features technology influence on their electrophysical characteristics was investigated on the basis of argentiferous pastes. Conducting layer specific surface resistances in a strong degree depend on modes of drying and burning-in. It is established, that the received layers roughness and their quality in a strong degree depend on the temperature speed increase [9].

The questions connected with structural phase transformations in systems based on "glass - Ag-Pd" during their manufacturing (drying, annealing) are actual and open.

\section{Experimental}

In the present work conducting thickfilm layers based on the heterogeneous ceramics "glass - Ag-Pd" systems during conductors and contact platforms formation the composition change was investigated with the purpose of finding-out its failure possible reasons.

Conducting layers were made on the basis of organic components: cyclohexanol, lanolin, ethylcellulose in $\alpha$-terpineol, petrolatum and leadborosilicate glass with extender from Ag, Pd particles. The particle sizes were fixed and amount to: glass $0.5-1 \mu \mathrm{m}$, conducting phase $-100-150 \mathrm{~nm}$.

Conducting contact platforms were formed by stencilling method on VK-94-1 ceramic substrates. Samples of two types differed by manufacturing technological modes were investigated: 1 -st type - drying at $150^{\circ} \mathrm{C}$, organic bond burning out $3000^{\circ} \mathrm{C}$, pastes burning in $-700^{\circ} \mathrm{C}$; 2 -nd type - drying at $150^{\circ} \mathrm{C}$, organic bond burning out $-500^{\circ} \mathrm{C}$, paste burning in $700^{\circ} \mathrm{C}$. Heat treatment of all samples was carried out in the normal conditions.

Infrared (IR) spectroscopy was applied, mainly, at investigation of gases, and also those liquids and firm bodies which are transparent in IR-area of spectrum. Structures "glass - Ag-Pd" are non-transparent for IR-radiation. However for creation such films which have stable and reliable characteristics the deep study of structural-phase transformations during film formation at its annealing, operation and storage is necessary. Obtaining of experimental data about similar processes nature meets a number of difficulties connected in one side with traditional physical and chemical research methods insufficient sensitivity, and in another side - with the new methods complexity.

In contrast to IR spectroscopy of transmission in which there is a number of the methodical restrictions caused by IR-radiation dispersion by adsorbent and full IR-radiation absorption by the adsorbent volume phase, the method of reiterated total reflection (RTR), using the falling of a light beam on a sample consisting of optical more dense medium under an angle more thpn critical, i.e. under conditions of total reflection, allows to obtain the information on films, adsorbed on firm body surface uniformity, phases, about the presence in films uncontrollable impurity, promotes studying surface layers formation procedure at vari- 


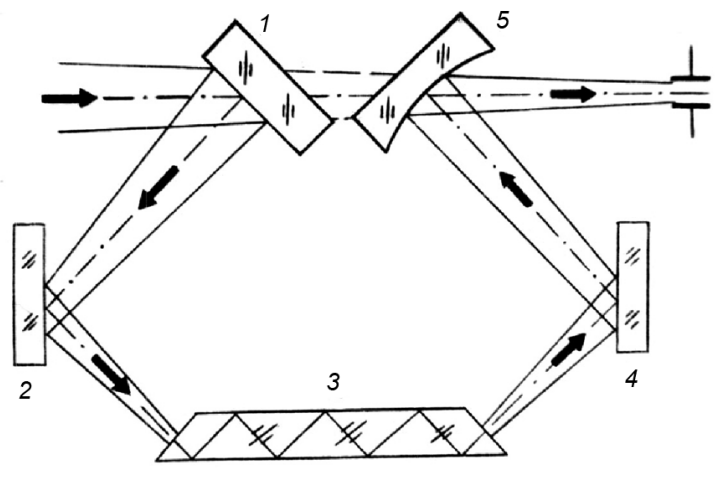

Fig. 1. The RFIR attachment optical circuit.

ous of temperature treatment modes and influence of an environment.

As IR method is nondestructive, rather simple and sensitive enough, in the work the attachment RFIR for spectrophotometer IRS-14A was developed which was allowed to investigate thin metals layers and composite materials.

The attachment optical circuit is presented in Fig. 1. Light stream from IR-spectrophotometer illuminator comes to forward flat mirror 1 and then to cylindrical mirror 2. With the help of these mirrors the image of a source is formed on an entrance side of the element 3 in a plane of the drawing and on exit side for the plane, perpendicularly to the drawing. After passage, the element RFIR light gets on flat mirror 4 and then with the help of toroidal mirror 5 the source image is projected in the plane of a photometric wedge. As RFIR spectra contrast depends first on number of reflections, in attachment the opportunity of the number of reflections change is stipulated within the limits of $5-50$ reflections depending on element RFIR which is used.

In the made attachment the total reflection element KRS-5 with the number of reflections equal to 10 is used. Such element was picked up from reflection optimum number necessary for metal film investigation (Table ).

In Fig. 2 IR RFIR spectra of the samples after temperature processing (drying) at $T=150^{\circ} \mathrm{C}$ are presented. Maxima with $\lambda=2850 \mathrm{~cm}^{-1}$ and $\lambda=2950 \mathrm{~cm}^{-1}$ testify the presence of methylene groups $\mathrm{CH}_{2}$ in the films which perform symmetric $\left(\lambda=2850 \mathrm{~cm}^{-1}\right)$ and antisymmetric valent oscillation. The small peak at $\lambda=2870 \mathrm{~cm}^{-1}$ corresponds to group $\mathrm{CH}_{3}$ symmetric valent oscillation and respectively to antisymmetric - at $\lambda=2950 \mathrm{~cm}^{-1}$. The fact that films,

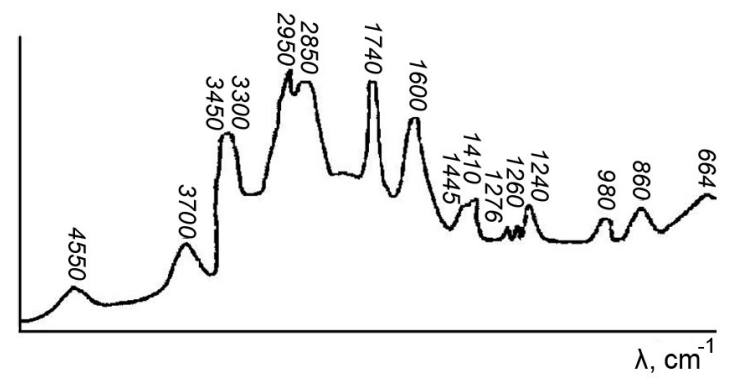

Fig. 2. IR RFIR spectra of samples, exposed to temperature processing (drying) at $T=150^{\circ} \mathrm{C}$.

Table Reflection optimum number for some metals at $\lambda=2100 \mathrm{~cm}^{-1}$

\begin{tabular}{|c|c||}
\hline Metal & $\begin{array}{c}\text { Reflection optimum } \\
\text { number }\end{array}$ \\
\hline Silver & 6 \\
Copper & 4 \\
Gold & 3 \\
Nickel & 2 \\
Platinum & 2 \\
The titan & 1 \\
Palladium & 1 \\
\hline
\end{tabular}

exposed under $T=150^{\circ} \mathrm{C}$, contain fatty substances components (for example, lanolin) justify the presence of maxima with $\lambda=1445 \mathrm{~cm}^{-1}$, appropriate to deformation oscillation of $\mathrm{CH}_{3}$, and also peak with $\lambda=$ $1240 \mathrm{~cm}^{-1}$, attributed to valent oscillation of $\mathrm{C}-\mathrm{O}-\mathrm{C}$ in ethers and to the absence of characteristic bands proper to replaced cyclohexatryene in $\lambda=1667-2000 \mathrm{~cm}^{-1}$ area. Other maxima are related, basically, to the various manner bounded water.

Under burning the organic bond in temperature mode of $T=300^{\circ} \mathrm{C}$ the sample IR RFIR spectrum character totally changes (Fig. 3). The peaks appropriate to adsorbed methyl, methylene and hydroxyl groups $(\lambda$ $=3700 \mathrm{~cm}^{-1}$ and $4550 \mathrm{~cm}^{-1}$ ) disappear. However the peaks at $\lambda=1830 \mathrm{~cm}^{-1}$, $1930 \mathrm{~cm}^{-1}$ and $2060 \mathrm{~cm}^{-1}$ appear.

\section{Results and discussion}

For correct interpretation of the received results conducting layers qualitative and quantitative chemical analyses were carried out. The analyses and spectra IR RFIR investigation data allow making the conclusion, that at temperature processing at $T=300^{\circ} \mathrm{C}$ on the conducting layer surfaces 


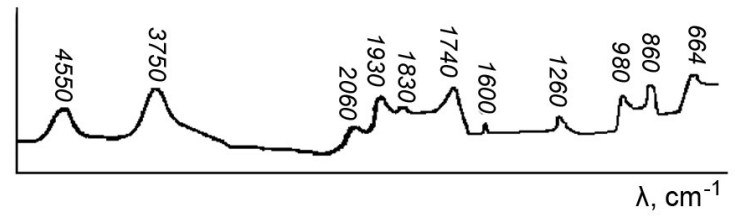

Fig. 3. IR RFIR spectra of samples exposed to temperature processing: drying at $T=150^{\circ} \mathrm{C}$ and a organic binding burning out at $T=300^{\circ} \mathrm{C}$.

carbon oxide chemisorbed structures are formed. Carbon oxide can form coordination compounds with metal atoms in which the molecule bounds with the metal by means of carbon atom. It occurs because in carbon oxid molecule there is $\sigma$-bound and two $\pi$-bound. Two electrons occupy loosening 2-molecular orbital, constructed, basically, from $2 s$ and $2 p_{x}$ - oxygen orbitals. Last two electrons are free pair and occupy $3 \sigma-$ orbital, which is formed by $2 s$ and $2 p_{s}$ carbon orbitals. At contact to metal $3 \sigma-$ molecular orbital, containing a pair of electrons overlap with vacant metal orbital with formation of $\sigma$-bound which bound carbon oxide with metal. Return electron transition from filled $3 \pi$-orbital of metal on vacant loosening $\pi$-orbital of carbon oxide is possible too. The processes leading to formation $\sigma$ and $\pi$-bonds partly increase both bonds durability. Donor $\pi$-bond from metal increases carbon oxide $3 \sigma$-orbital electrodonor properties. In turn, increased electrodonor character of $\sigma$-orbital increases carbon oxide acceptor properties at $\pi$-bond formation with metal. In multinuclear carbonyl carbon oxide can be bind with two metal atoms. In this case metal-carbon binds are covalent $\sigma$-bind.

On the basis of above-stated, maxima with $\lambda=2060 \mathrm{~cm}^{-1}$ can be interpreted as compounds of chemisorbed carbon oxide with the metal and oxide particles. Band with $\lambda=2060 \mathrm{~cm}^{-1}$ corresponds to bridge carbonyl type:<smiles>O=C([TeH])[Hg]</smiles>

However, taking into account an opportunity of carbon active chemisorption on conducting surface, it is possible to assume formation of compound of type:

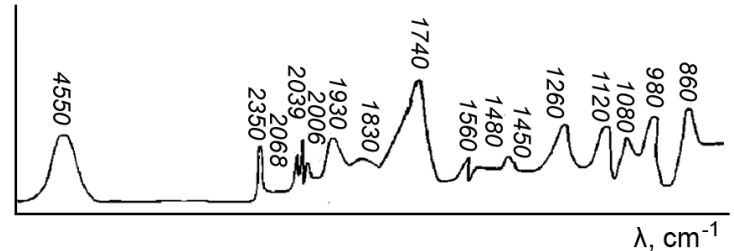

Fig. 4. IR RFIR spectra of samples, exposed to temperature processing: drying at $T=150^{\circ} \mathrm{C}$ and a organic binding burning out at $T=500^{\circ} \mathrm{C}$.<smiles>O=C[Te]C=O</smiles>

Maxima with $\lambda=1830 \mathrm{~cm}^{-1}$ and $\lambda=$ $1930 \mathrm{~cm}^{-1}$ correspond to carbon adsorption resulting in occurrence carbon oxide linear form with conducting film $\mathrm{O}=\mathrm{C}=\mathrm{Pd}$. The given maxima are intensive enough. Any impurity having electrodonor properties, will result in strips intensity reduction however without their displacement. The impurity participating in $\pi$-bound with metal formation, will reduce $\pi$-character metalcarbon bond and will result in strip carbonyl some shift in high frequencies area.

Organic binding burning out temperature elevation up to $500^{\circ} \mathrm{C}$ (Fig. 4) results in occurrence in IR RFIR spectra (except the maxima appropriate to carbonyl compounds of chemisorbed carbon in paste), peaks with $\lambda=2039 \mathrm{~cm}^{-1}$ and $\lambda=2060 \mathrm{~cm}^{-1}$ which in aggregate with $\lambda=2006 \mathrm{~cm}^{-1}$ correspond to end carbonyl groups valent oscillation absorption bands of type:

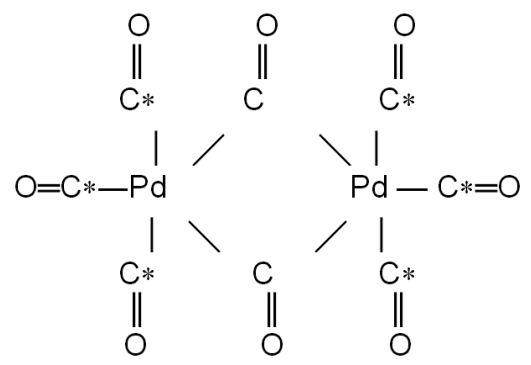

After temperature influence at $T=700^{\circ} \mathrm{C}$ in group 1 sample spectra only carbonyl peaks visualize (Fig. 5) whereas group 2 sample spectra (Fig. 6) except carbonyl peaks contain obviously increased end carbonyl group peaks and also gaseous $\mathrm{CO}_{2}$ absorption band $\left(\lambda=2360 \mathrm{~cm}^{-1}\right)$. Besides, in spectra carbide absorption bands $(\lambda=$ 


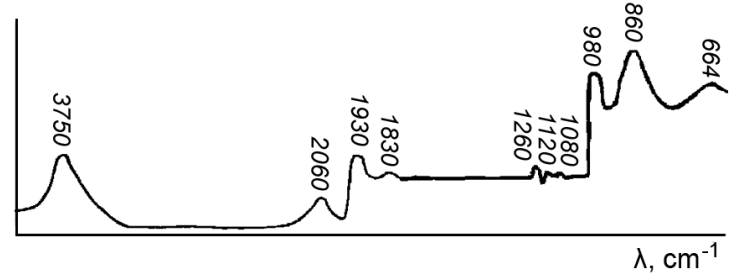

Fig. 5. IR RFIR spectra of samples exposed temperature processing: drying at $T=150^{\circ} \mathrm{C}$, organic binding burning out at $T=300^{\circ} \mathrm{C}$ and paste burning in at $T=700^{\circ} \mathrm{C}$ (type 1 samples).

$1080 \mathrm{~cm}^{-1}, \lambda=1122 \mathrm{~cm}^{-1}, \lambda=1560 \mathrm{~cm}^{-1}$ ) are observed.

The samples two-week keeping in the air has shown, that group 1 sample spectra practically have not changed. It testifies sample parameter stability to environment (air) influence. Group 2 sample IR RFIR spectra had significant changes. The absorption bands corresponding to carbonate ion have appeared, i.e. there was an interaction with the air moisture with the coal acid formation, the peaks connected with the capillary - condensed waters formation.

At the soldering such layer adhesion to a substrate was low, samples were characterized the increased fragility. By the chemical analysis are found out: free carbon (up to $15 \%$ ) and carbon as carbide (up to $2.1 \%)$.

\section{Conclusions}

Conducting thick-film layers based on "glass - Ag-Pd" nanocomposite system at temperature influence change its phase structure. At conducting films formation the organic binding full removal is necessary because the organic leavings in annealing process form in them carbide that results in their specific surface resistance increase. Besides the free carbon presence and its compounds reduces composite film adhesion to a substrate and worsens solderingability. With the help of IR RFIR-spectroscopy it is possible the film phase compound of composite putted on a ceramic substrate monitoring during their drying, organic binding burning out and annealing for the

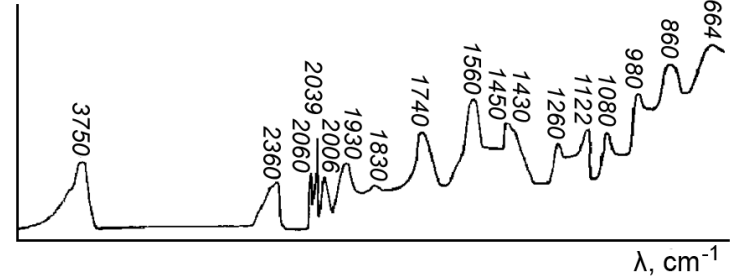

Fig. 6. IR RFIR spectra of samples, exposed temperature processing: drying at $T=150^{\circ} \mathrm{C}$, organic binding burning out at $T=500^{\circ} \mathrm{C}$ and paste burning in at $T=700^{\circ} \mathrm{C}$ (type 2 samples).

technological process optimum modes choice.

The composite film temperature treatment optimum modes are: drying at $T=$ $150^{\circ} \mathrm{C}$, organic band burning out at $T=$ $300^{\circ} \mathrm{C}$ and paste burning in at $T=700^{\circ} \mathrm{C}$. The temperature organic binding burning out raising up to $500^{\circ} \mathrm{C}$ results in occurrence in conducting layers end carbonyl groups, carbide, gaseous $\mathrm{CO}_{2}$, that results in layer embrittlement, low adhesion, bad soldering-ability.

\section{References}

1. V.G.Grebenkina, V.S.Dobroer, L.I.Panov, U.P.Trizna, Thick-film Microelectronics, Naukova Dumka, Kiev (1983) [in Russian].

2. N.S.Puchkova, A.N.Smirnov, A.I.Lazur, Techn. and Design. Electron. Equip., No.5-6, 58 (2000).

3. L.I.Panov, R.G.Sidorets, Techn. and Design. Electron. Equip., No.1, 43 (2002).

4. Ya.I.Lepih, T.I.Lavrenova, T.N.Bugayova, Bull. Kiev Nation. Univer. Techn. and Design, No.3, 126 (2013).

5. Sh.D.Kurmashev, T.I.Lavrenova, T.N.Bugayova, in: Proc. Intern. Scien. Conf. "Nanostructure Materials - 2010", Kiev (2010), p.329.

6. V.M.Proleyko, V.A.Abramov, V.N.Bryunin, Quality Management Systems of Microelectronics Devices, Sov. Radio, Moscow (1976) [in Russian].

7. N.I.Dokuchaev, I.Ya.Kozyr', D.I.Ononko, Testings and Measurements IBS, Izd-vo MIET, Moscow (1997) [in Russian].

8. L.Mattera, Electronics, No.20, 43 (1975).

9. A.V.Stolbikov, Yu.P.Erendeev, in: Proc. Intern. Symposium "Reliability and Quality", (2006), v.2, p.23. 